DOI: https://doi.org/10.32839/2304-5809/2021-7-95-6

УДК 780.8:780.616.432:78.03(477.81)(092)

Тарчинська Ю.Г.

Інститут мистецтв

Рівненського державного гуманітарного університету

\title{
ТВОРЧИЙ ПОЧЕРК ПЕДАГОГА-ПІАНІСТА НАТАЛІЇ ШИПУНОВОЇ
}

\begin{abstract}
Анотація. У статті здійснено першу спробу систематизувати методичні погляди знаного в Україні педагога фортепіанного класу Інституту мистецтв Рівненського державного гуманітарного університету - Шипунової Наталії Олександрівни. Орієнтовне окреслення особливостей їі фрахової діяльності охоплюе педагогічний та концертний аспекти творчого шляху мисткині. Аналіз педагогічного і виконавського стилю Н. Шипунової дозволив дійти висновку про те, що педагог розвивала музично-виконавську культуру майбутніх учителів мистецтва (музичного мистецтва) у кращих традищіях вітчизняної та европейської фортепіанних шкіл, що забезпечують сприятливі умови для ефективного фахового зростання здобувачів вищої музичної освіти. Н. Шипунова творчо втілювала фортепіанно-педагогічні засади видатних вітчизняних і зарубіжних педагогів-піаністів, професійна діяльність яких визначила розвиток української фортепіанної школи.
\end{abstract}

Ключові слова: Шипунова Н.О., викладач фортепіанного класу, педагогічна діяльність, фортепіанна школа, фрортепіанно-виконавське мистецтво.

Tarchynska Iuliia Institute of Arts,

Rivne State University of Humanities

\section{CREATIVE CHARACTER OF THE TEACHER-PIANIST - NATALIIA SHYPUNOVA}

Summary. The article is the first attempt to systematize the methodological views of the famous in Ukraine teacher of the piano class of the Institute of Arts of the Rivne State University of Humanities - Shypunova Nataliia Oleksandrivna. An approximate definition of the features of her professional activity covers the pedagogical and concert aspects of the artist's creative path. The teacher made a special contribution to the popularization of the Department of Music and Pedagogy, created in 1966 at the Rivne State Pedagogical Institute (now RSPU). During her professional career, she has trained more than thirty winners of prestigious international and all-Ukrainian competitions and festivals. Her concert performances delighted the audience of Ukraine and Europe. Analysis of the pedagogical and performing style of N. Shypunova made it possible to conclude that the teacher developed the musical and performing culture of future teachers of art (musical art) in the best traditions of domestic and European piano schools, which provide favorable conditions for effective professional growth of applicants for higher music education. N. Shypunova creatively embodied the piano-pedagogical foundations of outstanding domestic and foreign teachers-pianists, whose professional activities determined the development of the Ukrainian piano school. This gifted teacher directed the systemic individual development of future musicians-teachers, first of all, to the formation of a personality with high moral and volitional qualities, a demanding attitude to their own work, and proactive independent thinking. Its students strived to brightly and expressively convey to the audience the artistic image of works of musical art and the art of the form of embodiment of this image. In N. Shypunova's classes, interpretive work was understood as a deep penetration into the essence of musical images, the use of an integrated approach to mastering all performing tasks, calls for constant auditory control over the implementation of sound-creating tasks. In organizing her professional work, the teacher resorted to analysis and comparisons in the field of performing, pedagogical practices, her own activities and the characteristics of other piano schools. N. Shypunova's students pass on the traditions of their teacher's school to the next generations of young musicians. Of course, her professional heritage is worth further detailed research, and the memories of professional musicians brought up by the teacher can enrich professional methodological literature with interesting and useful material.

Keywords: Shypunova N. O., teacher of piano class, pedagogical activity, piano school, piano-performing art.

$\Pi$ остановка проблеми. Весь творчий шлях викладача фортепіанного класу Інституту мистецтв Рівненського державного гуманітарного університету Шипунової Наталії Олександрівни це шлях до високої мети: духовного збагачення, високоморального виховання молоді, досягнення істинності у втіленні змісту музичних творів, великої сили впливу мистецтва гри на фрортепіано. Ії особисті здобутки, успіх учнів педагога - результат непростого пошуку, помноженого на невичерпну волю, сміливість, наполегливість. Творчий шлях у музиці завжди супроводжуеться знахідками та сумнівами, успіхами та перешкодами. Н. Шипунова завжди вміла захищати внутрішній світ від зайвих життевих ситуацій, самостійно оцінювати власну працю, реалізовувати замислене. Всі ці особисті якості дозволили їй знайти свій неповторний педагогічний почерк, вартий уважного вивчення молодими педагогами-піаністами.

Аналіз останніх досліджень. Н. Шипунова належить до того типу людей, які постійно знаходяться в пошуках. Ці пошуки пов’язані з їі особистою творчістю та, звичайно, 3 педагогічною діяльністю. 31983 по 2020 рр. Наталія Олександрівна самовіддано працювала на кафедрі гри на музичних інструментах в Інституті мистецтв Рівненського державного гуманітарного університету (раніше - Рівненського державного педагогічного інституту). За час роботи в університеті педагог виховала 24 лауреата Міжнародних конкурсів та фрестивалів, 14 дипломантів Міжнародних і Всеукраїнських конкурсів. Інститут пишається їі студентами-переможцями таких престижних конкурсів і фестивалів як «Кримська весна», «Art-Klavier» 
тощо [3, с. 17]. За сумлінну пращю, концертну діяльність та підготовку студентів-лауреатів нагороджувалася 23 почесними грамотами, дипломами і подяками. За роботу у складі журі конкурсів, dpecтивалів була нагороджена 18 почесними грамотами Міністерства освіти України. У ï творчому доробку - більше 50 афрішних концертів в якості соліста, концертмейстера [2, с. 46]. Впродовж багатьох років вона також співпрацювала в якості концертмейстера 3 ансамблем скрипалів "Аріета» та зразковим дитячим хором "Ave Maria». Як солістка-піаністка і концертмейстер цих колективів Н. Шипунова виступала в Україні й за їі межами: у Франщії, Німеччині, Голландії, Швеції, Словаччині. Вона є автором наукових і навчально-методичних праць, серед яких 2 посібника, 13 методичних розробок, 10 наукових статей. Н. Шипунова була прийнята до таких фрахових спілок: асоціація педагогів-піаністів України, музична спілка України [1].

Свою початкову музичну освіту мисткиня здобула у Рівненській музичній школі № 1. Ї̈̈ наставником у цій школі була знаний рівненський педагог - Іда Савеліївна Ройтман, яка прагнула закласти гарне підгрунтя музичної освіти, виховати вдумливих музикантів, палко зацікавлених справою, прищепити почуття любові до музики, мистецтва, вона вчила своїх учнів долати складнощі, раділа їх успіхам, багатьом із них допомогла обрати шлях у житті [4, с. 501].

Серйозне професійне становлення Н. Шипунової продовжувалося у Рівненському музичному училиші та Львівській державній консерваторії ім. М. Лисенка. Зрештою, іï фрахове зростання не припинялося впродовж усього творчого життя педагога.

Однак насичена концертна, педагогічна та громадська діяльність Н. Шипунової відомі не достатньо широкому загалу. Та головне - досі ніхто не робив спроби систематизувати хоча б коротко методичні погляди знаного в Україні педагога.

Тож, мета статті полягає в оріентовному окресленні основних особливостей професійноі діяльності мисткині, яка виховала не одне покоління закоханих у свою справу музикантів.

Виклад основного матеріалу. Принциповим змістом роботи Н. Шипунової зі студентами було виховання розуміння і любові до академічного музичного мистецтва. Таке мистецтво, на переконання педагога, здатне формувати найкращі якості особистості, а високодуховне молоде покоління завжди було і буде потрібне Україні, світу.

Наталія Олександрівна знаходила абсолютно переконливі, іноді лаконічні, іноді розгорнуті, характеристики музичних образів, і це була не просто абстрагована розмова про художньо-образний зміст. Всі пояснення так чи інакше стосувалися проблемних моральних тем: страждання художника у несправедливих життевих обставинах, ностальгія за кращим, світлим у людській душі, пріоритетність духовного над матеріальним, пошук сенсу життя тощо. Глибоке естетичне переживання образу музичного твору мало втілюватись у виразному переданні емоцій виконавця. Тільки після такої визначеності у розумінні художньо-образного змісту можна було шліфрувати засоби виконавскьої виразності. Робота над виконавським нюансуванням власне спрямовувалася на шліфрування звуковедення і звуковидобування. До того ж робота над звукотворенням якнайтісніше пов'язувалася і 3 художнім образом твору, і 3 різноманітни- ми тембральними завданнями, і з технікою гри. Зміст музики, звук, техніка гри - все сприймалося у комплексі, взаємозв'язку та взаємозумовленості. Всі виконавські завдання підкорялися головному: свободі та яскравості втілення музичної думки, вільного втілення і з погляду техніки гри.

Н. Шипунова високо цінувала світ мистецтва і вміла завдяки власному прикладу виховувати в своїх учнях ту ж повагу і любов до прекрасного. Педагог прагнула інтенсивно розвивати усіх студентів, не зважаючи на різний рівень їх фортепіанної підготовки, індивідуальної обдарованості. До кожного студента ставилася спільна вимога: багато і усвідомлено працювати. До того ж стосовно більш здібних "планка" була вищою. Складні виконавські завдання обдаровані іï учні вирішували (як і їх педагог) завдяки непереборному бажанню безперешкодно донести поезію музики.

У клас Н. Шипунової зрідка потрапляли малообдаровані студенти. Тим не менше у роботі 3 такими учнями вона докладала титанічних зусиль для їх розвитку.

Наталія Олександрівна вчила студентів передусім згідно відомої формули: «вчить той, у кого вчаться». Ії власна творча робота відзначалася постійною посиленою увагою до фортепіанного мистецтва: це були аналіз та співставлення результатів своєї творчості на різних їі етапах, аналіз та співставлення особливостей різних фортепіанних шкіл, порівняння різних музичних творів - близьких та досить далеких стилів тощо. Цілеспрямований пошук асощіацій, аналогій або ж контрастів проводився у різних сфрерах: фортепіанно-виконавській, педагогічній, науково-методичній. Такий підхід розвивав творчі здібності, спонукав до постійного вдосконалення методичних поглядів.

Виконавський стиль педагога та їі студентів у чомусь зазнавали змін, але у чомусь завжди залишалися тим, що стали називати «шипуновською» школою. Однією з примітних рис виконавської манери вчителя та їі учнів завжди була і залишалася монументальність, виразність звучання фрортепіано, ораторська публіщистичність, яскрава емоційна насиченість, оркестральність звукових барв роялю.

Розвиток розглядуваного виконавського стилю відбувався в напрямі до поглиблення образно-змістових характеристик опановуваних фортепіанних творів, вдосконалення технічної підготовки студентів. Водночас вся робота супроводжувалася безперервною слуховою увагою до фрілігранності звукотворення. Студенти Н. Шипунової прагнули поєднати насичене, повнозвучне, виразно окреслене звуковидобування із надзвичайно контрольованою атакою звуку, витончено чутливим дотиком пальця до клавіші. Великого значення надавалося гарній відчутній опорі на клавіатуру вільної, «дихаючої» руки.

Надзвичайна увага в класі педагога приділялася мистецтву фрразування. Всі виразні засоби чітко підпорядковувалися логіці музично-смислового зв'язку. Тому, очевидно, виразне інтонування в класі Н. Шипунової сприймалося як беззаперечне, переконливе. Пильна увага до виконавського нюансування не дозволяла педагогу пройти повз найменші недоліки гри студента. Інколи впродовж тривалого часу міг опраџьовуватися один розділ, поки учень не почне «дотягуватися" до еталонного розуміння. Така пильність, помножена на активну звукотворчу волю, тримали безперервну увагу 
слухачів. Особлива вага у цьому впливі належала «живому» і наполегливому виконавському ритму.

Виконавський стиль Н. Шипунової та їі студентів досить рельефрно вирізнявся 3-поміж інших фортепіанних класів, але їі учні все ж порізному виявляли свою творчу індивідуальність. Також вони різною мірою викладалися у непростій піаністичній пращі. Проте сила впливу педагога на своїх вихованців була величезною. Тi, хто не міг впоратися із високими вимогами, не міг лишатися у їі класі. По-справжньому працелюбні, привчені у родині до чесної роботи, віддзеркалювали не лише якості піанізму наставника, а й багато рис характеру педагога: гарну самооцінку та вимогливість до себе, впевненість у власних силах, сміливість.

На фортепіанному занятті Наталія Олександрівна широко користувалася методом «показу» за інструментом. Це був не лише зразок бажаного виконання. Педагог у грі зверталася до аналогій, порівнянь, прагнула підняти інтелектуальну роботу до рівня узагальнень.

У роботі над звуковидобуванням завжди враховувався стильовий аспект. Пошук тембрального забарвлення, наприклад, у творах Ф. Шопена пов'язувався передусім із виявленням специфічного звучання "співного» фортепіано. В опануванні музики Й.С. Баха завжди обговорювалося інструментальне призначення того чи іншого твору клавірної спадщини композитора. Надзвичайно цікавими були оркестровки творів віденських класиків...

У пращі над технічними складнощами застосовувався традиційний аналітичний підхід. Водночас головним у грі будь-якого віртуозного епізоду було досягнення інтонаційної виразності. Втрата логіки звуковедення, нівелювання різних звукових рішень були незаперечною причиною відмови від передчасного переходу до швидшого руху.

У виборі репертуару тривалий час педагог надавала перевагу музиці композиторів-романтиків. Першорядне значення мали і музичні твори Й.С. Баха, віденських класиків. 3 роками стильовий спектр репертуару значно розширився. У класі звучали шедеври найрізноманітніших музичних стилів і течій XX ст., твори вітчизняних композиторів різних епох, у тому числі маловідомі композищії, відносно нещодавно віднайдені.

В опрацюванні музичних творів робота над деталями завжди проводилася в контексті худож- нього цілого. Водночас при цілісному охопленні музичної композиції детальне інтонування не приносилось у жертву на користь загального контексту. Крім методу "показу», майстерного володіння словом, педагог дуже часто застосовувала виразну жестикуляцію. Н. Шипунова володіла прекрасними вокальними даними і тому коригувала гру студентів також за допомогою співу.

Педагог виховувала у своїх учнях волю до переборювання складнощів, в тому числі у відповідальних і нелегких ситуаціях виходу на сцену та публічному виступі. Показовим у цому плані прикладом була участь i студентки у концерті кафедри. Всі учасники конщерту згідно задуму виходили на сцену із глядацької зали. Звичайно, останнім виступаючим доводилося найважче. Студентка Наталії Олександрівни приблизно із середини концерту дуже зосереджено почала готуватися до виходу на сцену. Вона малопомітно затулила вуха і працювала без інструменту з нотами на колінах. Опісля яскраво й енергійно завершила конщерт, ніби розпочинала вечір.

Висновки. Аналіз педагогічного i виконавського стилю Н. Шипунової дозволив дійти висновку про те, що педагог розвивала музично-виконавську культуру майбутніх учителів мистецтва (музичного мистецтва) у кращих традиціях вітчизняної та європейської фрортепіанних шкіл, що забезпечують сприятливі умови для ефрективного фрахового зростання здобувачів вищої музичної освіти. Н. Шипунова творчо втілювала фортепіанно-педагогічні засади видатних вітчизняних і зарубіжних педагогів-піаністів, профресійна діяльність яких визначила розвиток української фрортепіанної школи. Системний індивідуальний розвиток майбутніх музикантів-педагогів цей обдарований викладач спрямовувала передусім на формування особистості із високими моральними та вольовими якостями, вимогливим ставленням до власної праці, ініціативним самостійним мисленням. Ї̈̈ студенти прагнули яскраво й виразно донести до слухачів художній образ творів музичного мистецтва та мистецтво фрорми втілення цього образу.

Учні Н. Шипунової передають традищії школи свого викладача наступним поколінням юних та молодих музикантів. Звичайно, її професійний спадок вартий подальшого детального дослідження, а спогади вихованих педагогом професійних музикантів можуть збагатити цікавим і корисним матеріалом фрахову методичну літературу.

\section{Список літератури:}

1. Музично-педагогічна освіта / склад кафедри. URL: https://sites.google.com/view/musicalpedagogicalrshu (дата звернення: 19.07.2021).

2. Музично-педагогічному фракультету 40 років : бібліографічний довідник / редкол.: Є. Власов, М. Пономаренко, К. Устенко. Рівне : РДГУ, 2006. 78 с.

3. Рівненський державний гуманітарний університет - 75 років / упор.: Джеджера К.В., Дзюбишина Н.Б., Грипич С.Н. Рівне : Волинські обереги, 2015. 23 с.

4. Храм вічної музики. Рівненській дитячій музичній школі № 1 ім. М.В. Лисенка - 75 років / ред.-упор.: Б. Столярчук, С. Полевик. Рівне : О. Зень, 2014. 712 с.

\section{References:}

1. Muzychno-pedahohichna osvita / sklad kafedry [Music and pedagogical education / composition of the department]. Available at: https://sites.google.com/view/musicalpedagogicalrshu (accessed 19 July 2021).

2. Vlasov Ye., Ponomarenko M., Ustenko K. (2006) Muzychno-pedahohichnomu fakultetu 40 rokiv: bibliohrafichnyi dovidnyk [The Department of Music and Pedagogy celebrates 40 years: a bibliography]. Rivne: Rivne State University for the Humanities. (in Ukrainian)

3. Dzhedzhera K.V., Dziubyshyna N.B., Hrypych S.N. (2015) Rivnenskyi derzhavnyi humanitarnyi universytet 75 rokiv [Rivne State University of Humanities celebrates 75 years old]. Rivne: Volynsjki obereghy. (in Ukrainian)

4. Stoliarchuk B., Polevyk S. (2014) Khram vichnoi muzyky. Rivnenskii dytiachii muzychnii shkoli No 1 im. M.V. Lysenka - 75 rokiv [Temple of eternal music. Lysenko Children's Music School No. 1 in Rivne celebrates 75 years old]. Rivne: O. Zen. (in Ukrainian) 